\title{
Community-based Forest Management Policy and the Cultural Practices of the Sama Tribe
}

\author{
REYNALDO O. CUIZON \\ cuizonrey@yahoo.com.ph \\ University of Mindanao
}

Date Submitted: August 18, 2007

Final Revision Accepted: November 9, 2007

\begin{abstract}
The forest management concept is contradictory to Sama's forest protection and care and spirituality as confirmed by the nature and significance of the eight different rituals identified and the community's strong confidence in the epitomes of the tribe. The PO formation and establishment of partnership with it and with external agencies under CBFMA erode further the cultural practices of communal sharing and holding of commitment. The cultural practices of the Sama are founded on the values of sharing, commitment, and respect to the environment; CBFM promotes security of tenure and sub-contracting schemes. Sama's culture asserts no ownership of forest resources; CBFM deputizes $\mathrm{PO}$ members as ENRO, cultural practices emphasize the commitment of the entire tribe to protect and care for the environment; CBFM adheres to transparent allocation of monetary gains and to profit-making through commercial plantation, the cultural practices emphasize non-commercialization and non-offering of the forest resources to global competitiveness; CBFM goes for pricing the forest resources, cultural practices adhere to valuing and respecting the forest resources; and CBFM aggresses reforestation through plantation system, the cultural practices encourage non-excessive extraction and allowing the forest to replenish itself. The study concludes that CBFM is incongruous with Sama tribe cultural practices.
\end{abstract}

Key words - Cultural practices, Sama tribe, community-based forest management, policy analysis. 


\section{INTRODUCTION}

Enger and Smith (2006) have warned on the growing threat of global warming caused by human activity - a situation that calls for new approach of decision-making and interest in shaping public policy. Canadian Environment Minister David Anderson said, "The global climate change is a greater threat than terrorism because it could force hundreds of millions of people from their homes and trigger an economic and social catastrophe" (Cunningham \& Cunningham, 2006).

In undertaking environmental concerns policy that is culture-sensitive is necessary and "culture matters in public policy" (Hopped, 2007). Often, economic and political and not cultural implications are taken into account in policy analysis. Public policies are supposed to evoke a unitary and consensual governance culture (Van Gunsteren, 2002), and make culture an ally instead of an enemy, Hopped (2007) emphasized. Cultural consent solidifies government-people partnership in implementing public policy. A partnership built on respect for culture is robust (Vega, 2006). "Client analysis" to ensure cultural consent is a potent requirement in implementing public policy and one important question in evaluating such policy (Hayes, 1999).

The Philippine government responded to the global challenge of sustainable development. It committed to be "in compliance with the international commitments towards sustainable forest management" (DENR, 2005). Hence, it adopted and implemented the Community-Based Forest Management Policy.

While Werner \& Wegrich (2007,) insisted that "policy-making is supposed to contribute to problem solving or at least to the reduction of problem load", Linao (2004) and Carino (2005) respectively asserted that not all development programs or public policies are environment friendly. Some of them could be obstructive and hazardous to life and not culture friendly and could therefore be detrimental particularly to the indigenous people. It should be made sure that "development initiative will not offer the environment to the altar of global competitiveness" (Linao, 2005).

There have been several policy analysis researches done concerning forest management; however, all were within socio-economic and political realms; nothing analyzed Community Forest Management policy in the context of the cultural practices of indigenous communities.

The Tagbaobo's Sama tribe, a forest dependent and an indigenous people community, is definitely a target of the policy. Thus, its cultural practices may be used as basis and index to determine the validity and feasibility of the said policy.

As a factor of social development, public policy has to be analyzed; hence, this study was undertaken. 


\section{FRAMEWORK}

This study is anchored on three sets of theories. First, Vega (2006) and Hopped (2007) theorized culture as a way of life and it substantially helps predict policy's side effects and helps design policy-oriented learning experiences. It is an excellent heuristic in problem-structuring and frame-reflective policy analysis. Culture's components are communicative, cognitive, behavioral, and material. Second, Werner and Wegrich (2007) on time-segment theory on policy analysis postulated that policy analysis can be ex ante or ex post. The study utilized Nagel's Conceptual Theory and Policy Evaluation focused on goal, strategy, and goal-strategy connection elements using systematic and analytic method of either quantitative or qualitative or both to determine validity and feasibility of the policy (Hayes 2002). Third, are the theories that explain the acceptability of public policy on whether the interests and viewpoints of its proponents and the culture of the indigenous communities affected are aligned to it or not. Culture demands comprehensive considerations from observation to the level of in depth analysis (Enger \& Smith 2006). A multidisciplinary approach is necessary if one has to examine the interrelationship of the culture-based systems and the aim and management of techno-social change as consequence of development pursuits (Yanow 2007).

\section{OBJECTIVES OF THE STUDY}

The study was pursued to describe the cultural practices of the Sama tribe and to utilize such information as a contextual paradigm to determine the validity and feasibility of the Community-Based Forest Management Policy. Specifically, this study sought to achieve the following objectives: (1) to describe the demographic profile of the Sama Tribe in Tagbaobo; (2) to portray the cultural practices of Sama tribe; (3) to determine the congruence of the goals and strategies of Community-Based Forest Management Policy with the cultural practices of the Sama tribe.

\section{METHODOLOGY}

This study is descriptive (Calderon \& Gonzales, 1993) using qualitative-interpretive (Yanow 2007) and quantitative methods. The categorization through coding system led to quantitative interpretation of the recurring themes, compare and contrast responses, and link up information to unverified criteria (Colton and Covert 2007). Frequencies of occurrence of the coded qualitative data and statistical correlation between values were determined through tabular presentation. Convenient sampling technique was used among Sama people from Tagbaobo, Island Garden City of Samal.

The data collection procedure started from integrating in the community to reviewing the documents and synthesizing-analyzing process focused on the cultural practices of Sama people and the core and rundown goals of Community Based Forest 
Management. Core goals are referring to the main and specific intention of the policy. The data analysis included documentation, transcription, and categorization using emergent coding system, validation, and complementation.

\section{RESULTS AND DISCUSSION}

Culturally, the Sama people are mountain and sea-source dependent, communal by nature, confident to their Datu, Balyan, Magbubungay and old folks as leaders, respectful to the spirits as stewards of creation, faithful to Magabaya, and protective and caring for the environment.

The Rituals with specific materials used as symbolisms are Sama's concrete medium of its commitment to Magbabaya in protecting and caring for the environment. The Manuwak, Magdayao, Guwang, Pangapog, Abugon, Manawagtawag, Magbana, and Manganiyani rituals manifest the significance of the environment and the values of the tribe. Performing the rituals offensive to cultural practices is wickedness. The aggressor will suffer from sapa (curse).

Table 1: Sama tribe rituals and corresponding materials used and values indicated

\begin{tabular}{lll}
\hline \multicolumn{1}{c}{ Ritual } & \multicolumn{1}{c}{ Concern } \\
\hline Manuwak & Drought & Sharing, humility and mercy \\
Magdayao & Irregularity & Comfort and reconciliation \\
Guwang & Death & non-ownership of land, supremacy of land \\
Pangapog & Festivity & Thanksgiving and sharing \\
Abugon & Curse & Reparation and forgiveness \\
Manawagtawag & Sick & Healing (using herbs and indigenous way) \\
Magbana & Calamity & Harmony with nature/ commitment to protect the tribe \\
Manganiyani & Tree-cutting & Respect, truthfulness and simplicity \\
\hline
\end{tabular}

The Sama people practice eight rituals: Manuwak, Magdayaw, Guwang, Pangapog, Abugon, Manawagtawag, Magbana, and Manganiyani. Manuwak performed in humility during drought aims to ask for mercy and rain. People manifest and intensify their values on sharing during this crisis. Magdayaw is observed during eccentric situations to alleviate problems and promote reconciliation. Guwang is done during death of a community member to remind people the non-ownership and supremacy of land. Pangapog is celebrated for thanksgiving and sharing of bounties. Abugon is performed to cast away curse in the community through reparation and forgiveness. Manawagtawag is honored to heal sick person. Here people learn the significance of herbs and respect indigenous way of healing. Magbana is accomplished when calamities strike the community. This ritual reminds the people the importance of caring for the environment and nature. Manganiyani is feted to truly respect and ensure the spirits of the ultimate purpose of the timber.

Table 2: Frequency distribution of the goals of CBFM

\begin{tabular}{lccccccccc}
\hline \multicolumn{1}{c}{ Goals } & \multicolumn{2}{c}{ Social } & \multicolumn{2}{c}{ Political } & Economic & \multicolumn{2}{c}{ Cultural } & Total \\
& No. & $\%$ & No. & $\%$ & No. & $\%$ & No. & $\%$ & \\
Core Goals & 2 & 100 & & & & & & & 2 \\
Rundown Goals & 1 & 14 & 4 & 57 & 2 & 29 & 0 & 0 & 7 \\
\hline
\end{tabular}


Liceo Journal of Higher Education Research

The study revealed that the goals and strategies of CBFM can be divided in two levels: the core and rundown. While the core goals are all inclined to social interest, fifty seven percent (57\%), twenty nine percent (29\%) and fourteen percent $(14 \%)$ of its rundown are political, economic and social in nature. Nothing is inclined to cultural aspect.

The three general strategies of CBFM are well distributed to economic, political and cultural aspects (Table 4). CBFM's core strategy stating respect indigenous culture has not been justified in its rundown strategies. The rundown strategies are inclined to economic (45\%) and political (45\%) aspects; while less to social $(10 \%)$ and nothing to cultural (Table 5). This matches and corresponds with the orientation and inclination of the CBFM goals where $86 \%$ are also biased for political and economic targets.

Table 3: Frequency distribution of the General Strategies of CBFM

\begin{tabular}{ccccccccccc}
\hline Strategies & \multicolumn{2}{c}{ Social } & \multicolumn{2}{c}{ Political } & \multicolumn{2}{c}{ Economic } & \multicolumn{2}{c}{ Cultural } & \multicolumn{2}{c}{ Total } \\
& \multicolumn{1}{c}{ No. } & $\%$ & No. & $\%$ & No. & $\%$ & No & $\%$ & No. & $\%$ \\
General Strategies & & 0 & 1 & 33 & 1 & 33 & 1 & 33 & 3 & 100 \\
\hline
\end{tabular}

The table shows that the general strategies of the Community Based Forest Management are equally focused on the political, economic and cultural aspects. There is nothing falls under social aspect. This implies that the policy does provide social benefit to the intended and affected community.

Table 4: Frequency distribution of the Rundown Strategies of CBFM according to social, political,

\begin{tabular}{ccccccccccc}
\multicolumn{10}{c}{ economic, cultural aspects } \\
\hline Strategies & \multicolumn{1}{c}{ Social } & \multicolumn{1}{c}{ Political } & Economic & Cultural & \multicolumn{2}{c}{ Total } \\
\hline \multirow{2}{*}{ Rundown } & No. & $\%$ & No. & $\%$ & No. & $\%$ & No. & $\%$ & No. & $\%$ \\
\hline
\end{tabular}

The table shows that among the societal aspects, most of the rundown strategies of the Community Based Forest Management are politically and economically intended. Only $10 \%$ and nothing at all fall under social cultural aspects respectively. It means that the policy is culturally sensitive and responsive.

Table 5: Frequency distribution of the Rundown Strategies of CBFM according to type of service

\begin{tabular}{lcccccccc}
\hline Strategies & Marketing/ Business & \multicolumn{3}{c}{ Organizing } & Funding & \multicolumn{2}{c}{ Total } \\
& \multicolumn{1}{c}{ No. } & $\%$ & No. & $\%$ & No. & $\%$ & No. & $\%$ \\
Rundown & 9 & 39 & 12 & 52 & 2 & 9 & 23 & 100 \\
\hline
\end{tabular}

In can be gleaned from the table that more than half $(52 \%)$ of the rundown strategies of Community Based Forest Management policy is articulated for organizing pursuits. This is followed by marketing/ business and funding which comprise 39\% and $9 \%$, respectively. The figures confirm that half of the concerns of the policy are money making interest related and other half is for structure and community building. That is, the policy confides with profit-making and funding related means or activities to achieve desired targets. 
Table 6: Congruity of CBFM Goals and Strategies and Sama Cultural Practices

\begin{tabular}{|c|c|c|c|}
\hline Element & CBFM & Sama Cultural Practices & Decision \\
\hline Goal & Promotion of social justice & $\begin{array}{l}\text { Communal sharing } \\
\text { Spirituality and environmental }\end{array}$ & Congruent \\
\hline Goal & $\begin{array}{l}\text { Promotion of healthy } \\
\text { environment }\end{array}$ & $\begin{array}{l}\text { practices are interconnected and } \\
\text { inseparable. Healthy environment is } \\
\text { founded on and in respect with the } \\
\text { cultural practices }\end{array}$ & Congruent \\
\hline Goal & Sustaining forest management & $\begin{array}{l}\text { Commitment to environmental } \\
\text { protection and care is innate to every } \\
\text { member of the tribe }\end{array}$ & Incongruent \\
\hline Goal & $\begin{array}{l}\text { Increasing community } \\
\text { involvement }\end{array}$ & & \\
\hline Strategy & $\begin{array}{l}\text { Respecting IP rights and culture } \\
\text { Uplifting socio-economic } \\
\text { investment and contribution, } \\
\text { global competitiveness, increase } \\
\text { revenue and income of } \\
\text { communities and LGUs }\end{array}$ & $\begin{array}{l}\text { Aspirations on rights to ancestral } \\
\text { domain and self determination } \\
\text { Environmental resources are not for } \\
\text { global competitiveness but for local } \\
\text { consumption; based on the needs of the } \\
\text { community, not for business and profit. }\end{array}$ & Incongruent \\
\hline
\end{tabular}

Pricing forest products

Strategy

Strategy

Strategy

Giving benefits: land tenure, linkage, foreign funding, land rental and forest charges exemption, income and proceeds share, and access to financial assistance. Allowing and encouraging massive harvesting scheme social equity, market capital and

\section{Rehabilitating the forest by means of implementing commercial plantation and reforestation scheme \\ Strategy Implementing Forest Resource Securitization Strategy} spirituality of sharing not of monetary earnings but materials, tools, time, and labor founded in the spirit of trust, confidence, and reliance with the Datu, Magbubugay, Balyan and old folks. All environmental (forest) resources are valuable but it is absurd to put a price on something given by Magbabaya for free.
Conserving the forest and giving it the opportunity to replenish and regenerate itself.

Commitment to protect and care for the environment cannot be via contractual scheme (especially with profit-oriented agencies)

Strong cultural structure with reverence to the tribal leaders, healers and cultural transmitters
Incongruent

Incongruent Incongruent members become ENRO 
In view of the summary presentation of the Community Based Forest Management policy goals and strategies against the Sama people cultural practices (Table 6), it appears that while the policy's core goal and strategy are congruous with the Sama cultural practices, some goals and all rundown strategies obviously do not conform to and substantiate the Sama tribes's cultural practice. The rundown strategies do not even articulate the one considered a cultural-oriented strategy. The Community Based Forest Management has more of economic and political interests', which are incongruent with the cultural interest and practices of the Sama people.

\section{CONCLUSIONS}

The study found that the Community Based Forest Management is concerned with healthy environment and social justice through equitable access to forest resources. Likewise, the Sama cultural practices stress the inseparability of environmental practices from indigenous spirituality and the value of communal sharing. In as far as core goal is concerned the policy is congruous with the Sama cultural practices. However, as far as rundown goals are concerned, the policy is into political and economic rather than social and cultural. It involves uplifting of socio-economic condition of the community, enhancing of private investment, economic contribution and global competitiveness, and increasing revenues and incomes of communities and LGUs. These rather reflect monetary earnings out of excessive extraction of resources. The values manifested by the rituals imbibe communal sharing within the essence of integrity of creation and minimalist character of utilizing resources.

The rundown strategies of the policy do not essentially articulate its culture-oriented core strategy. Terms like land tenure scheme, market capital and linkage, equity and share of proceeds, foreign funding, forest resource securitization strategy, incentives such as exemption from rentals and forest charges, assistance of environment-concerned agencies, pricing and commercialization of forest resources, livelihood and plantation projects, and contractual scheme have more economic and political inclination as means rather than social and cultural interventions. They do not exemplify the indigenous spirituality, values and aspirations vis-à-vis environmental concerns. The Sama people value the sharing of forest resources, and the pure intention extracting resources. Sama cultural practices curb tree plantation for commercialization and excessive extraction of forest resources. They uphold forest natural self-replenishment process.

The policy's concept of forest management is contradictory to the cultural belief that forest should not be taken as a separate entity from the entire environmental concern. "Forest management" is incongruous with "environmental protection and care". The policy is incongruent to the cultural practices of the Sama people. 


\section{LITERATURE CITED}

Calderon, J. F., and Gonzales, E. C. (1993). Methods of research and thesis writing. Mandaluyong City: National Bookstore.

Carino, Jill. (2005). An assessment of the implementation of the philippine government's international commitments on traditional forest-related knowledge from the perspective of the indigenous people.

Colton, D. \& Covert, R.W. (2007). Designing and constructing instruments for social research and evaluation. San Francisco, CA: John Wiley \& Sons, Inc.

Cunningham, W. \& Cunningham M.V. (2006). Principles of environmental science: Inquiry and Application. New York: Third Edition. McGraw-Hill.

Defensor, M. T. (2005). National report to the fifth session of the United Nations forum on forest. Forest Management Bureau, Department of Environment and Natural Resources. Government of the Philippines.

DENR (2005). Forest Management Bureau National Report.

Enger, E.D.\&Smith, B.F.(2006). EnvironmentalScience: a study on interrelationship. McGraw-Hill, Inc. NY

Hayes, W. (2002). The public policy Web. whayes@ramapo.edu.

Hopped, R. (2007). Applied cultural theory: too for policy analysis. Handbook of Public Policy Analysis. New York: CRC Press, Taylor and Francis Group

Linao, R. (2004). Community immersion: towards becoming agents of community empowerment. Q.C. Philippines: Great Books Trading.

Trochim, W.M. (2001). The research methods knowledge based (2nd ed.). Cincinnati, $\mathrm{OH}$ : Atomic Dog.

Werner, J. \& Wegrich, K. (2007). Theories of the policy cycle. Handbook of Public Policy Analysis. New Yoirk: CRC Press, Taylor and Francis Group

Van Gunsteren, H. (2002). Regimes as cultures (unpublished paper)

Vega, V. A. (2006). Social dimensions of education. Q.C. Philippines: Lorimar Publishing, Inc.

Yanow, D. (2007). Qualitative-interpretive Methods in Policy Research. In Fischer, F et al. (Ed), Handbook of public policy analysis: theory, politics and methods (405-415). FL, U.S.: CRC Press, Taylor \& Francis Group 